ODRODZENIE I REFORMACJA W POLSCE • SI 2017 • PL ISSN 0029-8514

Janusz Tazbir

\title{
Polish Echoes of St. Bartholomew's Day Massacre
}

1

The polemics resulting from Paris bloody events of August 1572 has had - so far - few studies in European literature. ${ }^{1}$ Years ago Wacław Sobieski expressed his intent to write a special study on this subject, ${ }^{2}$ but he did not manage to perform his plan. Numerous polemic materials (mostly Monluc's speeches and his opponents' refutations) became the subject of a more detailed discussion in the works of Traczewski and Noailles $^{3}$ (the latter even quotes substantive fragments

${ }^{1}$ Cf. A. Elkan, Die Publizistik der Bartholomeusnacht und Mornays Vindicias contra tyrannos (Heidelberg, 1905; Heidelberger Abhandlungen, no. 9); C. Lenient, La satire en France ou la littérature militante aux XVI siècle, vol. 2 (Paris, 1877), pp. 12f., and contributions at a colloquium held in Paris: Actes du colloque "L'Amiral de Coligny et son temps", Paris, 24-28 octobre 1972 (Paris, 1974), esp. by R.M. Kingdon, A. Molnar, and L. Makkai. Recently, a special issue of Revue d'Histoire Littéraire de la France (73 [1973], no. 5) was focused on St. Bartholomew’s Day with, i.a., articles: J. Baibé, "La Saint-Barthélemy dans la littérature française"; J. Pineaux, "Poésies protestantes au XVIe siècle après la Saint-Barthélemy"; J. Giraud, "Pibrac, Elvide, Machiavel"; R. Pintard, H. Carbie, "Ressouvenirs de la Saint-Barthélemy au XVII e siècle".

${ }^{2}$ W. Sobieski, Polska a hugonoci po nocy św. Barttomieja (Kraków, 1910), p. 9. Cf. also J. Tazbir, "La nuit de la Saint-Barthélemy, ses échos en Pologne," in: Actes du colloque "L'Amiral de Coligny", pp. $427 \mathrm{f}$.

3 A. Traczewskij, Polskoje bieskorolewije po pieriekraszczenii dinastii Jagiellonow (Moskwa, 1869); E. de Noailles, Henri de Valois et la Pologne en 1572, vol. 1-3 (Paris, 1867). Both authors, as far as polemic literature is concerned, frequently used French translations and reprints contained in the sixteenth-century publication Mémoires de l'Estat sous Charles IX, vol. 1-3 (Heidelberg, 1578). 
thereof). Nevertheless, the subject is far from being exhausted, especially that the dispute reached the majority of European countries; thus, the brochures distributed in the Commonwealth were printed (or prepared) not only in Poland but also in France and Germany or even Austria. Already in the period 1572-1574, in connection with Valois' attempts to become Polish king, hundreds of pages were written on this subject and although they contain a lot of rhetoric padding, and arguments (and counter-arguments) are monotonously repeated, the detailed presentation thereof could be subject of a separate book. The more so that - as Sobieski rightly stated - the French St. Bartholomew's Day did not make such an impression anywhere else and "did not cause such fluctuations in the public opinion" as it did in Poland. ${ }^{4}$

It was due, first of all, to the fact that from the beginning of the mass development of Reformation in the gentry this class particularly carefully watched religious wars in Western Europe, especially in France, which - according to written opinions - had flooded with Christian blood and where "few healthy noblemen and not ruined towns were left". ${ }^{5}$ Secondly, contacts with this country were particularly vivid, especially with respect to the Polish and French followers of Calvin. Our compatriots could be met not only at the French universities; they also listened to religious discussions (for example, the famous colloquium in 1561 in Poissy was attended by Mikołaj Dłuski from Iwanowice and Krzysztof Thretius), and sporadically they even participated in armed fights of Catholics with Huguenots. ${ }^{6}$ Poles also had many friends in heretics' camp in France. Thirdly, there is no doubt that the most important reason for the interest in St. Bartholomew's Day events was the fact that the person, who was generally considered in Europe to be co-guilty of this massacre (even if not its main culprit) wanted to be elected king of Poland.

We are not really aware how difficult it was to grant Polish crown to Henry Valois a year after the Paris events. On the one hand, Poland was already considered a "heretics' shelter", 7 and on the other, St. Bartholomew's Day was a shock in almost all of Europe. Except for pope

${ }^{4}$ Sobieski, op. cit., p. 8.

5 Pisma polityczne z czasów pierwszego bezkrólewia, ed. J. Czubek (Kraków, 1906), p. 549.

${ }^{6}$ Cf. J. Moreau-Reibel, "Sto lat podróży różnowierców polskich do Francji," Reformacja $w$ Polsce 9-10 (1937-1939), pp. 4f.

7 Cf. J. Tazbir, Dzieje polskiej tolerancji (Warszawa, 1973), pp. 57f. 
Gregory XIII and Philippe II, the majority of European royal courts (not only the Protestant ones) expressed strong indignation. Almost overnight France lost the credit of trust, and its ruling class was an object of sharp attacks. ${ }^{8}$ But while in other countries the faithlessness and cruelties of the massacre were mostly condemned, in Poland, where a nobleman could not be imprisoned without a court verdict, the murder - at the king's order - of so many representatives of gentry was rather considered a symptom of the worst possible tyranny than yet another bloody act of religious war. ${ }^{\text {? }}$

The shock that the Paris events had caused in Poland was already substantially described by Sobieski. ${ }^{10}$ When news about St. Bartholomew's Day reached the public "within a few hours [as Monluc's secretary Jean Choisnin admitted] French name was subject of everybody's disgust". ${ }^{11}$ And when the writings and drawings presenting details of the massacre arrived from Paris, they ruffled emotions so much "that it was almost impossible to mention the names of the king, queen mother and the Duke of Anjou". ${ }^{12}$ The gentle sex, when speaking about such crimes, apparently cried so profusely as if "it was an eyewitness of that dreadful history".

So we see how difficult Monluc's situation was, since he was sent to Poland to persuade the gentry to elect Henri Valois king of Poland. The Bishop of Valencia left Paris a week before the massacre (17 Aug. 1572); on his way he was nearly murdered as a crypto-Huguenot. ${ }^{13}$ In Saint-Dizier he heard the news about the Huguenot massacre, but he continued his travel; on 15 October he entered Poland (in Międzyrzecze). He stayed in Budzisław at Ląd Castellan Stanisław Wysocki's estate and from there he sent letters to the senators who, from 25 October, held a meeting in Kaski (Sochaczew District), in which he recommended the French candidate. We do

${ }^{8}$ Cf. n. 1; Noailles, op. cit., vol. 2, pp. 136-141; Traczewskij, op. cit., pp. 300-301.

9 Similarly, the Spanish Inquisition was in Poland considered both, religious persecutions and ruthless violation of gentry's civic rights.

10 Sobieski, op. cit., pp. 11-12.

${ }^{11}$ J. Choisnin, O elekcyi Henryka Walezyusza na króla polskiego. Pamiętniki (Wilno, 1818), p. 89.

12 Ibidem, p. 109.

${ }^{13}$ In Grzybowski's opinion these suspicions were not far from the truth, cf. S. Grzybowski, "Sylwetka polityczna i wyznaniowa Jana de Monluc," Odrodzenie $i$ Reformacja $w$ Polsce 6 (1961), p. 63. It was even suspected that the Bishop of Valencia was "in some unknown understanding" with certain Protestant circles. 
not exactly know when they reached their addressees; anyway, within twenty four hours from the receipt thereof the news about St. Bartholomew's Day reached Poland. ${ }^{14}$ Monluc was in despair and he cynically wrote to Paris that if they really wanted to put the French prince on the Polish throne they should have at least adjourned the massacre of Huguenots. ${ }^{15}$ The situation seemed absolutely hopeless, especially if we take into account the slow pace of the exchange of correspondence between Poland and Paris. For a long time Jean Monluc did not get any instructions from his court and he did not know what the official version of the Paris events was. ${ }^{16}$ On top of that, the bishop of Valencia did not have a large group of co-workers or sufficient funds. Nevertheless, he managed to overcome all these problems and the manner in which he conducted the political-religious propaganda and influenced the gentry's opinion ${ }^{17}$ is one of the main subjects of our article.

Being absolutely aware that the main issue was to "win" the gentry, and its representatives "ne pouvoient estre gagné que par longues harrangues et discours semez par le pays" (and in a language understood by the recipients) ${ }^{18}$ Monluc focused on conducting propaganda by way of elusive polemic brochures. He mostly wrote them himself, ${ }^{19}$ and his writings can be divided into two groups: the first contains his speeches delivered on 10 and 25 April 1573 in Kamień near Warsaw (published in Polish, Latin and French). The second group of Monluc's works contains loose writings defending the Duke of

${ }^{14}$ This shows that the detailed news on the Paris massacre reached Poland only two months later.

15 Sobieski, op. cit., p. 24; Traczewskij, op. cit., p. 308.

16 S. Grzybowski, Szpada Pana Admirata. Dzieje hugenotów (Warszawa, 1961), p. 114 , rightly notices that the court itself provided the two subsequent, mutually contradictory explanations of the genesis of the events.

17 On this cf. J. Maciszewski, "Mechanizmy kształtowania się opinii publicznej w Polsce w dobie kontrreformacji," in: Wiek XVII. Kontrreformacja. Barok. Prace z historii kultury, ed. J. Pelc (Wrocław, 1970); J. Tazbir, "La propagande politique et sociale de la contre-réforme en Pologne," Il Pensiero Politico 5, no. 1 (1972), pp. 44-61.

18 Mémoires de l'Estat, vol. 1, p. 259.

${ }^{19}$ A precise specification is provided by K. Estreicher, Bibliografia polska, vol. 22 (Kraków, 1908), pp. 544-546. The majority of polemic works from that period (cf. ibidem, vol. 18 [Kraków, 1901], pp. 104-110, s.v. "Henryk Walezy" et al.) was reprinted (together with refutations) by the aforementioned publishers of Mémoires de l'Estat. 
Anjou, such as Vera et brevis descriptio tumultus postremi Gallici Lutetiani, in quo occidit Admiralius cum aliis non paucis, ab origine sine cuiusquam iniuria facta (Cracowiae, 1573), or Defensio pro Illustrissimo Andium Duce adversus quorundam calumnias, 1574 (also translated into French ${ }^{20}$ ) or Epistola... ad Poloniae Ordines de Illustrissimo Andium Duce in Regnum Polonicum allegando (28 Oct. 1574). These brochures were accompanied by other works such as Ornatissimi cuiusdam viri de rebus gallici ad Stanislaum Elvidium epistolae (Lutetiae, 1573) by Guy de Pibrac, also distributed in Poland. ${ }^{21}$

Monluc's (and his supporters') reasoning on the genesis of St. Bartholomew's Day was subject to certain changes, similarly as propaganda carried out by the French court and relating to other issues. ${ }^{22}$ Initially, House of Guise and its quarrel with Chatillon family was considered responsible. In this approach Charles IX played the role of pacifier who was sorry about the massacre. But soon the pressure of the House of Guise forced the king to issue a statement that the admiral's followers prepared a plot against the court; to prevent it, Charles IX ordered to imprison the perpetrators, which turned - against his intent - into massacre. The third version relatively close to the truth was that the king - following senate's advice - preferred to order the murder of the plot leaders than to allow them to put the country into the fatal abyss of civil war. ${ }^{23}$

All these interpretation differences were reflected in Monluc and his supporters' brochures. So in the brochure anonymously published by the Bishop of Valencia Vera et brevis descriptio tumultus postremi Gallici Lutetiani, which was the earliest, we read that civil war in France resulted from the conflict between two wealthy houses (House of Guise and House of Chatillon), in which Charles IX

${ }^{20}$ Cf. Noailles, op. cit., vol. 2, p. 128.

21 This work under the French title Epistre d'un excelent personnage de ce royaume faite par forme de discours, sur aucunes choses depuis peu de temps advenues en France, became quite popular in Europe and was subject to numerous replicas from Protestants - cf. Giraud, op. cit., passim.

22 On this propaganda Noailles, op. cit., pp. 131-133, 136-137.

${ }^{23}$ According to the latest research of French historians the plan of Huguenots' massacre was not arranged in advance. It was after unsuccessful attack on the admiral that made Catherine de Medici provoke - for fear of Huguenots' revenge - the massacre; nevertheless, it is certain that Henry of Anjou (not Charles IX) was the actual leader of the Catholic camp (and, consequently, the co-organizer of St. Bartholomew's Day); cf. J. Héritier, Catherine de Médicis (Paris, 1959), pp. $412 \mathrm{f}$. 
unsuccessfully played the role of a pacifier. And when in 1568 there appeared a chance for peace, the admiral, with the help of German mercenaries once again unleashed religious war; antagonism between Coligny and House of Guise was presented here as the main reason for internal fights.

Huguenot noblemen wanted to take an armed revenge on the House of Guise for the attack on the admiral. Luckily, the king was informed about the prepared plot and asked Henry Valois for advice. The latter advised him to disregard warnings; but Charles IX ordered the killing of the plot leaders, and only thirty Huguenot noblemen were killed. The whole town took up arms, further fifty victims were killed, and five thousand in the country, in spite of the fact that the king did everything he could to prevent the spreading of uproars. At the request of the king, an investigation against the perpetrators was instituted; Henry Valois played a very positive role in these events; earlier, he had done everything he could to prevent riots and now he helped the victims thereof.

The same arguments (only partly modified) were presented by Monluc in Defensio, which was published in Latin as late as 1574; he recalled Huguenots' cruelties during civil wars and firmly negated the idea that the Paris massacre had been deliberately prepared in advance. But after hurting the admiral, Huguenots, not satisfied with the king's promise that he would punish the guilty ones, began to get ready for fight. When their plot was discovered, the king, in order to avoid a fourth civil war, ordered to imprison Coligny and two hundred outstanding leaders. Unfortunately, people of Paris, always eager to initiate riots, got engaged in the conflict and together with soldiers and admiral's enemies they attacked Huguenots. Forty noblemen (not 1200 as the opponents state) fell victims to the massacre. The king was not cruel, which is reflected in the fact that he called on other towns to keep peace and not follow Paris. Unfortunately, six of them did not obey and riots burst out there. The work is ended with the praise of softness and nobleness of Henry Valois, who had nothing to do with these events.

Monluc's arguments were elaborated by other writers, the particularly important of whose is Guy de Pibrac, the author of Ad Stanislaum Elvidium epistolae. ${ }^{24} \mathrm{He}$ also wrote that the king was sorry about injuring the admiral, but when Charles IX visited him, he behaved in

24 This work was reprinted in a summary form by Noailles, op. cit., pp. $147 \mathrm{f}$. 
a provoking way, showing his revenge intent. ${ }^{25}$ On the following day the king was informed about the plot which Coligny prepared not only against the House of Guise, but also against the House of Valois. Charles IX's advisors recommended then - for the good of the country - choosing the lesser evil, that is, execution of the plot leaders without a court trial and evidence procedure. The king, who was known for his softness and law-abiding, first protested against such solution, but senators explained to him that taking a different way he would bring a terrible misfortune on France and a fourth civil war. Charles IX was very sad but he followed this advice; he repeated several times the order to kill only the leaders "afin que les innocens n'endurassent pour les coupables". ${ }^{26}$ Unfortunately, when people of Paris, deeply attached to Catholicism, heard that Huguenots had prepared a plot aimed at the murder of the king and burning of the town, they attacked them. Pibrac stresses the merits of Henry of Anjou, who opposed the fury and cruelty of the mob and protected the threatened. Thanks to his goodness he put an end to the recent two civil wars, and he did everything he could to prevent the Paris incidents.

Monluc, similarly, when defending (in the speeches delivered in April of 1573 at the Polish Sejm) Charles IX against accusations of cruelty, recalled that through the gentle treatment of Huguenots he wanted to end civil wars. Alas, fights exploded again "and it was due to religious differences and conflict between the prior houses". ${ }^{27}$ Monluc repeated the version which we already know: only the leaders of the plot were supposed to be punished. It was hoped that in this way the civil war would not be transferred from the Netherlands to France, since this would "result in the fall of this kingdom aggravated for such a long time". In this situation, according to the Senate's advice Charles IX "had to agree to the fateful killing of the admiral and other noblemen at the pressure of all princes and Paris Senate (which is very powerful in our country)". Thus, Paris massacre exploded "against the hopes and awareness of all". ${ }^{28}$ Monluc also blames "the poisonous mob" and states that the king failed to prevent the transfer of massacre to the provinces.

As arguments defending Henry Valois against the accusation of being the co-organizer of the massacre Monluc mentioned his softness

${ }^{25}$ Ibidem, p. 151.

${ }^{26}$ Ibidem, pp. 153-154.

27 J. Monluc, Legacyja na elekcyjej króla nowego polskiego (Kraków, 1573), fol. $\mathrm{E}_{\mathrm{IV}} \mathrm{ver}$.

${ }^{28}$ Ibidem, fol. $\mathrm{F}_{\mathrm{V}}$. 
and chivalry. The prince was very sorry that "slaughterers and vile mob beat" those whom he used to overcome only in open battles. Even if he had not been driven by nobility, he should have prevented St. Bartholomew's Day out of sheer calculation since he knew well that this may destroy his reputation in Poland and make his way to the throne more difficult. Monluc used various methods to dispel the fears that electing Henry may subject Poland to similar persecution of dissenters and civil war as destroyed France. He recalled the personal virtues of the candidate and stressed that regulations applicable in Poland guaranteed that no riots "for religious differences" could explode. ${ }^{29}$

It seems that he had a rather negative opinion (and he was partly right) on the gentry's knowledge about what really happened in Paris. He was probably also aware of the low intellectual level of certain deputies (especially from Mazovia region), to whom he addressed his speeches. Anyway, he did not limit himself in selection of arguments; he considered all of them good if they let to accomplish the goal. People even laughed that "if he was requested to build a golden bridge across Vistula River, he would answer - it is not a problem". ${ }^{30}$ He promised everything to everybody: no wonder that later he was accused by everyone of not keeping his promises. ${ }^{31}$ It seems that Pibrac and Monluc had several common features as publicists trying to justify the events of the tragic St. Bartholomew's Day. Both of them did not really believe in the genuineness of their own arguments. Both Monluc and Pibrac were undoubtedly political followers of Machiavellianism, which was very popular at that time; any means was good if it led to the goal. This is why in confidential conversations Monluc could explain to certain persons that the Polish crown was attractive to Henry just because of the tolerance (since he hated lording of the clergy), and he persuaded others that the Duke of Anjou was the a committed defender of faith, which he showed during the Paris events. ${ }^{32}$ Bishop of Valencia, being already familiar with Polish

${ }^{29}$ Ibidem, fol. $\mathrm{F}_{\mathrm{II}}$ ver.- $\mathrm{F}_{\mathrm{IV}}$ ver. This speech was reprinted in a not very precise version by W.S. Broel-Plater, Zbiór pamiętników do dziejów polskich, vol. 3 (Warszawa, 1858), pp. $112 \mathrm{f}$.

30 S. Płaza, Próby reform ustrojowych $w$ czasie pierwszego bezkrólewia (1572-1574) (Kraków, 1969), p. 243.

31 Sobieski, op. cit., pp. 142, 150.

32 Traczewskij, op. cit., pp. 317-318; see also T. Piliński, "Bezkrólewie po Zygmuncie Auguście i elekcyi króla Henryka," Przegląd Polski (July, 1868), p. 47. 
relations, never wrote a word praising Huguenots' massacre and kept repeating that Henry Valois had nothing to do with it. The contemporary researchers suspect that both publicists were driven by pro-Huguenot intents, since Monluc attempted to convince Polish Protestants to demand numerous important concessions for their co-religionists from the French king, and Pibrac (called by Giraud "défenseur sans conviction intime, avocat sans bonne foi") could - the same as Monluc - hope that getting rid from France of the main perpetrator of St. Bartholomew's Day would facilitate pacification of religious relations in France. ${ }^{33}$

These two writers and other Catholic defenders St. Bartholomew's Day were characterized by attempts to present these events as mainly political ones, as a plot against the king. The plot even more despicable because its leaders would not refrain from the worst crime, that is crimen lesae maiestatis (murdering the king). ${ }^{34}$ Besides Calvinist magnates led by the admiral (who was presented as an ambitious, ruthless politician and the main obstacle to religious peace in France), the second scapegoat of Monluc, Pibrac and other Catholic polemists' attacks was the mob. It was presented as a dangerous social force, which is easy to incite by affecting its fanaticism and attachment to dynasty or the revenge and plunder desire. This luck of trust to the mob is constantly present in religious polemics, also in Polish Counter-Reformation. ${ }^{35}$

One of its leading representatives Jan Dymitr Solikowski not only translated into Polish two speeches of the Bishop of Valencia (of 10 and 25 April 1573), but also belonged to the few publicists of the period of first interregnum who defended the perpetrators of St. Bartholomew's Day. In Rozmowa kruszwicka (conducted by Piast with the Guest) he presented the version of the Paris events, which was identical with Monluc and Pibrac's reasoning. In the opinion of the Guest (who is Solikowski's alter ego), the French king as a good politician must have known, first, that popular riots is such a big town as Paris were easy to incite but difficult to end up. Second, Charles IX attempted to keep peace for such a long time that it is unlikely that he wanted "to deliberately destroy it". It is also not true that thousands of people were killed, "although even one life is regretted when an innocent person dies".

\footnotetext{
33 Giraud, op. cit., pp. 807, 818. Cf. n. 13.

${ }^{34}$ Ibidem, p. 811.

35 Cf. Tazbir, "La propagande," p. 59.
} 
Solikowski repeats the version which we already know, according to which Huguenot noblemen wanted revenge for hurting the admiral. "So they organized a plot to hit the castle at night, kill Guises, and the king could also be exposed to danger". When informed about it, Charles ordered "to catch the conspirators", but Henry Valois did not want to accept it. In the meantime the conspirators hit the Louvre from behind and began a fight against the royal guards, in which "up to 30 persons" were killed. The town people joined the fight "and in this awful riot several hundred people were killed in the town and the admiral was also killed", and about five thousand were killed in the provinces. At the king's order "severe inquisitions followed as to who caused these riots". It is not true that the admiral's wife was killed, "of whose belly, as they write, an unborn baby was ripped out, and other things unworthy of noble eyes and ears". "Henry Anjou's face shows that he has not a drop of tyrant blood, only gentleness, benignity, wisdom, bravery, and great attachment to knight's work". As we see, Solikowski did not try to invent his own original arguments; his reasoning was almost a copy of the already discussed Latin brochures (especially of Vita et brevis descriptio by Monluc). ${ }^{36}$

The reasoning of the numerous defenders of the Paris massacre ${ }^{37}$ was not difficult to oppose; in many brochures published in France, Switzerland or Germany the blame was put on the Machiavellianism of the Valois House (personified in Catherine de Medici and her compatriots), ${ }^{38}$ and on intolerant policy of French kings (first of Henry II, and later Charles IX). In the Protestants' opinion, these factors and not religious differences or conflicts of the houses incited internal wars in France. The thesis of the alleged Huguenot plot was challenged; it was stated that it was Charles IX and Catherine de Medici, who brought Protestants to Paris as to a trap, to murder them; the frequent thesis

36 Pisma polityczne, pp. 486-488; cf. also E. Kotarski, Publicystyka Jana Dymitra Solikowskiego (Toruń, 1970), pp. 45-46, 126.

37 Attempts to present Huguenots as political rebels and perpetrators of civil wars are also found in other works from the period of the first interregnum, cf. Pisma polityczne, pp. 509, 513. And Solikowski introduced - as a provocation - St. Bartholomew, who supported Duke of Valois in the work defending Henry (written already after his escape from our country), cf. ibidem, pp. $613 \mathrm{f}$.

${ }^{38}$ Cf. S. Grzybowski, "Z dziejów ksenofobii francuskiej w czasach wojen religijnych," Odrodzenie i Reformacja w Polsce 10 (1965), pp. 109-110. It should be stressed that, as it results from the findings by Polish researchers (especially by H. Barycz), in attacks against Machiavellianism St. Bartholomew's Day events were never referred to as an example of applying this concept in practice. 
about Coligny and his comrades preparing political coup was negated. The number of victims was challenged; according to Protestants it was about several dozen thousand. All cruelties committed during the massacre were described in detail. And noble intents of Coligny, who was a loyal subject and a faithful servant of the king, were stated. Since this polemics was mainly aimed at reducing Henry's chances to become Polish king, his opponents kept repeating that he was the main perpetrator of the massacre, because he was a cruel and insidious enemy of the freedom of Protestant religion. ${ }^{39}$

Some Wolfgangus Prisbachius, signing himself as Cracoviensis (and Polonois in the French translation $)^{40}$ took part abroad in this polemics. In 1572 a collection of German epigrams was published in Vilnius (Illustrium aliquot Germanorum carminum liber). Its main subject was "a versatile study in the literary form of the motives of St. Bartholomew's Day massacre", and its goal was to make the whole Valois dynasty abominable to Poles. ${ }^{41}$ It was clearly stressed in the sub-title, where we read: "on the big and pathetic slaughter of Christians by the godless and cruel tyrants of France in Paris of 1572". Henry Valois was called Herod, tyrant, Muslim and Turks' ally. The events of that awful night were described in detail: "Children, old men and sick people are killed. The killers leave bloody traces everywhere; fear of death is everywhere, as well as crimes". Special part was focused on Charles IX, who, in the authors' opinion, was even worse in barbaric acts and faithlessness than Ivan the Terrible. Separately the authors condemned the Lorraine Cardinal (Charles de Guise) and Catherine de Medici; perpetrators and participants of the massacre were described as cruel and godless criminals. The very Pope Gregory XIII was also condemned for his approval for the inspirers of the slaughter. ${ }^{42}$

In another pamphlet written in the period of the first interregnum the authors jeered at the Western candidates and accused Henry Valois

${ }^{39}$ Brochures on this subject are reprinted in Mémoires de l'Estat, vol. 1-2; cf. also Sobieski, op. cit., passim.

${ }^{40}$ Cf. Mémoires de l'Estat, vol. 2, pp. 28f. Latin title: Responsio ad orationem habitam nuper in concilio helvetiorum, pro defensione caedium et latrocinium quae in Gallia commissa sunt... Auctore Wolfgangus Prisbachius Cracoviensi.

41 Illustrium aliquot Germanorum carminum liber de immanissima miseranda Christianorum laniena ab impiis et crudelissimis Galliae tyrannis (Lutetiae Parisiorum, 1572); Una cum epicediis et epitaphiis (Wilno, 1573); on this work cf. J. Nowak-Dłużewski, Okolicznościowa poezja polityczna w Polsce. Pierwsi królowie elekcyjni (Warszawa, 1969), p. 30.

42 Nowak-Dłużewski, op. cit., pp. 30-32. 
that several thousand of his subjects "paid with their lives for this wedding. Here you have a pure hetman; here you have a pure king". 43 The same accusation is repeated by another polemist, who describes how Charles IX invited a monarch equal to him to Paris and promised to give him his sister as wife, "but he ordered to murder the sleeping guest and eight thousand persons, princes and noblemen [- - . Indeed, the cruelty and cheating that this good monarch and other persons accompanying him experienced had never happened after Christ's birth" ${ }^{44}$ One can quote more of similar statements, ${ }^{45}$ for example in 1576 the translation of the work O furyjach albo szalenistwach francuskich, to jest o strasznym a niestusznym Amirata Kasztyllionskiego i wielu innych mężów zamordowaniu was published in Łosk. It was translated by Szymon Budny, and its author was Edmundus Waramundus Frisiles; Franciszek Hotman hid himself (in Kot's opinion) under this penname. ${ }^{46}$ Budny wanted to block Henry Valois the way to the throne. But it was published much too late.

These issues were also discussed after Henry's escape and in the polemics related to the hedging of Warsaw Confederation; we will discuss these statements in the further part of our article. Now we would like to discuss the very technique of carrying out the propaganda, which, in spite of all obstacles, resulted in the election of St. Bartholomew's Day co-perpetrator the king of a state famous for tolerance.

Monluc tried, first of all, to distribute his brochures in the biggest possible editions. Noailles writes about thousands of copies, and it does not seem to be exaggerated (certain brochures were published in 1500 2000 copies). ${ }^{47}$ If needed, scribes were employed; when certain speech by the Bishop of Valencia had to be quickly copied, 20 scribes worked on it three days without any break, and then it was distributed among the Members of Parliament. ${ }^{48}$ But Monluc had only a few co-workers, ${ }^{49}$

${ }^{43}$ Broel-Plater, op. cit., vol. 2, pp. 49-50.

${ }^{4}$ Pisma polityczne, p. 355.

45 Cf. ibidem, pp. 499, 692.

46 S. Kot, "Szymon Budny. Der grösste Häretiker Litauens im 16. Jahrhundert," Wiener Archiv für Geschichte des Slawentums und Osteuropas 2 (1956), p. 94. The work $O$ furyjach albo szalenistwach francuskich (On French furies or madness) has, unfortunately, not survived to our times.

${ }^{47}$ Noailles, op. cit., p. 67. Let us recall that the average edition of a scientific book in sixteenth-century Poland was up to 500 copies.

48 Traczewskij, op. cit., p. 435.

${ }^{49}$ Monluc sent up to 30 letters every day, most of which he wrote himself, and which supported Henry as a candidate, cf. Choisnin, op. cit., p. 113. 
and anti-French Protestant prints were distributed in Poland, the Bishop of Valencia kept asking Paris for sending him some new co-workers or prints justifying the massacre.

The court did not hurry to fulfil his requests; French ambassador Guy de Lansac, who was supposed to explain the August events to the deputies, appeared as late as March instead of the beginning of January $1573 .{ }^{50}$ Huguenots willing to justify the murderers of their coreligionists were worth of their weight in gold. Tireless Monluc found such a person - Jean de Sechelles, who came to Poland at the end of February $1573 .^{51}$

But the opponents did not let grass grow under their feet: first of all, numerous Huguenots who had been in France (or even in Paris) in August of the previous year arrived; there are also Poles among them

Those, who had been in your country at that time,

and had seen you murder Protestants even in their sleep. ${ }^{52}$

One of them was Jan Łasicki, Calvinist scholar and polemist, who saved his life by pinning a cross to his cap (which was the habit of Catholics on St. Bartholomew's Day), because, as he stated later, "in other case I would be dead". The death of his beloved master and coreligionist Jan Ramus traumatized him, the same as having seen naked corpses thrown into waste dumps and piles of dump, or straight into the Seine. His stories about the Paris slaughter were widely known in Poland and Lithuania, "providing a new medium to the horror and martyrdom motifs in Reformation journalism and historiography". ${ }^{53} \mathrm{He}$ was accompanied by Jan Krotoski, ${ }^{54}$ the later Inowrocław castellan. Both managed to come back to Poland before the election Sejm of 1573 and they told around about their impressions. These stories caused Krotoski's father,

${ }^{50}$ Noailles, op. cit., vol. 2, p. 141.

${ }^{51}$ Cf. Sobieski, op. cit., pp. $70 \mathrm{f}$.

52 Ibidem, pp. 12, 29. Eye witnesses of the slaughter were also brought at the expense of Calvinist congregation (cf. ibidem, pp. 40f.). This resulted partly from the postulate of Calvinist magnates, who agreed to resign from support of Henry Valois providing they would receive the unbiased information about the course of St. Bartholomew's Day, as that received by them so far did not satisfy them, cf. N. Ljubovicz, Naczato katoliczeskoj reakcji i upadok reformacji w Polsze (Warszawa, 1890), p. 236.

53 H. Barycz, Jan Easicki. Studium z dziejów polskiej kultury naukowej XVI wieku (Wrocław, 1973), pp. 92-93.

${ }^{54}$ Cf. a biography J. Krotoski’s by R. Żelewski in Polski stownik biograficzny, vol. 15 (Wrocław et al., 1970), pp. 345-346. 
also Jan, Inowrocław voivode, to take such a hostile attitude toward Henry as a royal candidate that Monluc had to find three other Polish noblemen, who, as alleged witnesses of Paris events, presented them in a completely different light. ${ }^{55}$ And when in August 1573 Polish deputies came to Paris, they had an opportunity to hear authentic coverage from the slaughter witnesses, who survived; the Protestant members of the delegation were indignant to hear that on the anniversary of the slaughter a solemn holy service took place in Paris churches. ${ }^{56}$

It is understandable that a particularly active campaign against Valois as a royal candidate was carried out by Geneva Calvinists, who inspired their Polish coreligionists to do the same (which Sobieski writes a lot about). To persuade Luther followers to go the same way, rumours were spread that Henry hated them even more than Calvinists. But similarly as Monluc, who found witnesses among venal Calvinists, Catholics, for political reasons, were also against Valois as candidate. So Austrian agents spread brochures showing Henry "as the main perpetrator and inciter of Paris murders". Jesuits from Ingolstadt even dared to use provocation: they allegedly wrote a "panegyric" praising Henry, in which he occurred as "comme premier inventeur, autheur et violent solliciteur, conducteur et brave exécuteur" of St. Bartholomew's Day. Juxtaposing Charles IX and Henry of Anjou, they compared the first of them to David (since he killed only one thousand Huguenots), and the latter to Goliath (who murdered ten times more people). This pamphlet was apparently sent to Cracow. ${ }^{57}$ The Spanish delegate Pedro Fajardo did a similar thing: he distributed in Poland the alleged letter of Lorraine Cardinal to Commendone, in which Charles de Guise tried to win over the pope's legate by stating that if he supported Henry, he would make another St. Bartholomew's Day in Poland. ${ }^{58}$ Agitation was also carried out in churches, and Calvinist ministers of the Cracow congregation violently attacked Henry in their sermons as the main perpetrator of the slaughter. ${ }^{59}$

55 Sobieski, op. cit., p. 18.

56 The files on this diplomatic mission: Diariusz poselstwa polskiego do Francji po Henryka Walezego w 1573 roku, ed. A. Przyboś, R. Żelewski (Wrocław, 1963); on the mass cf. S. Orzelski, Bezkrólewia ksiag ośmioro, 1572-1576 (Kraków, 1917; SSRP, vol. 22), p. 144.

57 Sobieski, op. cit., p. 10, n.; Th.-A. D’Aubigné, Histoire universelle, vol. 1 (Amsterdam, 1626), colls. 609-610.

58 Traczewskij, op. cit., p. 405.

59 Sobieski, op. cit., p. 172. 
Besides oral messages and printed propaganda the iconography was also used; this method was already used in political propaganda of that time. We know about priests' caricatures spread by the Reformation circles or images with which Polish Brethren attacked Catholic dogma on the Holy Trinity ${ }^{60}$ (it was a sort of Biblia Pauperorum a rebours). So almost every week drawings and sketches "with descriptions of different tortures and ways of murdering" were sent from Paris to Poland. "They also showed women, whose bellies were ripped and unborn babies were ripped out". These drawings presented Charles IX and Henry Valois; with appropriate gestures and words (added on the text) they encouraged "the furious mob [- $]$ to spill blood", and condemned participants for being too merciful and for not cruel enough conduct. ${ }^{61}$ Monluc, on the other hand, distributed in Poland the portraits of Henry Valois and indicated that his face had not a trace of cruelty. ${ }^{62}$

Eye witnesses and appropriate propaganda resulted in the fact that almost all the interested parties were aware of the bloody course of St. Bartholomew's Day, even though some of them let the propaganda (according to the rule, as Piliński writes - mundus vult decipi) persuade them that Henry Valois had nothing to do with it. ${ }^{63}$ In negotiations with the candidate to the Polish throne the Protestant gentry did not forget about the demand that Charles IX was to eliminate the effects of St. Bartholomew's Day, therefore, not only announce a general amnesty for Huguenots and grant religious freedoms to their denomination, but also offer compensation to the families of the Paris slaughter victims. In the fifth part of the famous Postulata polonica they required Charles IX to give back the heirs of the murdered "Parisiis mense augusto et postea per aliquot Galliae urbis" their positions and goods which they had and had held. If those positions had already been sold, he had to return their monetary value. The same applied (return of property and positions) to emigrants, whereas Catholics who - against tolerance edicts - took part in slaughters, Charles IX should severely punish. ${ }^{64}$

${ }^{60}$ K. Górski, Grzegorz Pawet z Brzezin. Monografia z dziejów polskiej literatury arianskiej XVI wieku (Kraków, 1929), pp. 202-208. Sketches showing the Spanish torturing Indians significantly contributed to spreading "the black legend" about the Spanish.

${ }^{61}$ Choisnin, op. cit., p. 108.

${ }^{62}$ Noailles, op. cit., vol. 2, p. 127.

${ }^{63}$ Piliński, op. cit., p. 178.

${ }^{64}$ Diariusz poselstwa polskiego, pp. 5-6; Sobieski, op. cit., pp. 87-88. This last demand was an indirect hit against the House of Guise. 
Each person who had been forced after the slaughter to give up Calvinism was to be able to return to this denomination. Monluc accepted these postulates on behalf of the future elect; this was one of the main reasons that Valois was elected Polish king. Of requests contained in Postulata polonica Charles IX fulfilled only a part; Polish diplomatic mission failed to win any rights for the families of the victims of St. Bartholomew's Day.

But its echoes are clearly noticeable in the text of the resolution passed by the Warsaw Confederation; according to the unanimous opinion of historians, from Noailles to contemporary researchers; it would not have been passed if not for the fear that the Paris massacre may be repeated in Poland under the rule of Henry. ${ }^{65}$ This is why, to avoid "any harmful riots between the people, which can be observed in other kingdoms", even Catholics (including bishop Krasiński) endorsed the aforementioned legal act. He tried to justify himself to canons and wrote clearly about "recent French examples" showing what intolerance may lead to. ${ }^{66}$ Therefore, Monluc fulfilled his propaganda mission only partly: he did not manage to free his candidate from the odium of co-perpetrator of the Paris massacre. The very election of Henry resulted from the conviction that he would have to observe the national rights (thus restricting him with the Henrician Articles, the genesis of which also reflects the fear of a repetition of St. Bartholomew's Day in Poland). This is firmly reflected in a characteristic example quoted by Sobieski: the Royal Treasurer, Calvinist Hieronim Bużeński, warned Monluc not to try to convince him that Henry "did not take part in this slaughter and was not a cruel tyrant", because ruling in Poland "he would rather have to be afraid of his subjects and not vice versa". ${ }^{67}$ Therefore, no wonder that the Polish political system seemed an ideal to Huguenots and the conviction about an exceptionally tolerant character of Poles was widespread in Europe. ${ }^{68}$

${ }^{65}$ Cf. Noailles, op. cit., vol. 2, pp. 208-209, 215-217; Sobieski, op. cit., pp. 14-15, 19 et al.; S. Salmonowicz, "Geneza i treść uchwał konfederacji warszawskiej," Odrodzenie i Reformacja w Polsce 19 (1974), p. 14.

${ }^{66}$ Cf. T. Gostyński, Franciszek Krasiński, polityk złotego wieku (Warszawa, 1938), p. 109, 144-145. Its genesis was similarly explained by K. Warszewicki, "Rerum polonicarum... descriptio," in: Opuscula inedita (Varsaviae, 1883), ed. T. Wierzbowski, pp. 34-35.

${ }^{67}$ Sobieski, op. cit., p. 13.

${ }^{68}$ Ibidem, p. 181; S. Kot, Rzeczpospolita Polska w literaturze politycznej Zachodu (Kraków, 1919), pp. 31-32. 
The events of St. Bartholomew's Day caused that Polish political journalism is full of such proverb-like expressions as "French slaughters", "French fire" and expresses fear of things going "French". Of the multitude of statements on religious wars going on there we will quote a few: Jan Niemojewski in his polemics with H. Powodowski wrote about thousands and thousands of people murdered in France and the Netherlands (1583), descriptions of hunger accompanying the siege of Paris were read, ${ }^{69}$ and representative of Czech Brothers, Szymon Teofil Turnowski wrote: "martyrs' blood flooded in France. And the war still lasts" (1595). ${ }^{70}$ And Lew Sapieha stated in 1590: "I am a Catholic but I do not wish my homeland to experience what happened in France". ${ }^{71}$ In 1592 one of the polemists wrote: "Frenchmen have fought against their brothers for several dozen years" due to religious differences, which harms their nation and state, while Poles managed "to prevent such awful war through the Confederation". ${ }^{72}$ This opposition of the Warsaw Confederation and St. Bartholomew's Day is frequent in Polish written works eager to oppose the tradition of Polish tolerance against fratricidal religious fights taking place in other countries.

It became proverbial, the same as Sicilian Vespers had been before, and with which Paris events were often compared. Sigismund III was suspected that if it had not been discovered in advance, his wedding with Archduchess Anna "would have looked like St. Bartholomew's wedding". ${ }^{73}$ For the next one hundred years these events were quite often referred to in Poland; for the first time this was caused by the mood of bitterness triggered off not only by Valois' escape but also by offensive poems of his French companions about Poland. The reply to Desportes' work "so offensive for national pride" was Odpowiedź przez Polaka wszetecznemu Francuzowi, in which we read that on St. Bartholomew's Day

${ }^{69}$ Nowiny z Francyjej o wybawieniu miasta Paryża od oblężenia króla nawarskiego (Kraków, 1590); Skuteczne opisanie śmierci Henryka III Walezyjusza (Kraków, 1590).

70 Wybór mów staropolskich, ed. B. Nadolski (Wrocław, 1961; Biblioteka Narodowa, Ser. 1, no. 175), pp. 198-199.

${ }^{71}$ Archiwum domu Radziwittów (Kraków, 1885; SSRP, vol. 8), p. 206.

72 Sobieski, op. cit., p. 20.

73 Diariusze i akta sejmowe r. 1591-1592, ed. E. Barwiński (Kraków, 1907; SSRP, vol. 21), p. 105. 
Several dozen murdered (as they say)

Anger almost devil-like and poisonous dogs' day...

Fury rules here as in speechless beasts

Or in fat Tartars who walk around in bonds.

Paris slaughter was also mentioned by Kochanowski in his famous poem Gallo crocitanti, where he stated with pride:

No Sicilian grim bells will be heard from our churches.

Poland is not that bloody country, notorious for vespers.

You criticize us that we get drunk and fall asleep during the feasts wrote the poet - thanks God this has not happened in Paris, because there a sleeping person may not wake up anymore, and "bleeding corpses are thrown out of the windows".

If you, my Gall, had the choice, would you prefer to jump through the window or to fall drunk under the table? ${ }^{74}$

No doubt that the king's escape caused gallophobia, ${ }^{75}$ in which memory of the Paris slaughter was present. The anonymous author of the poem Apologeticus (probably Stanisław Niniński ${ }^{76}$ ) expressed his conviction that Cardinal Jerzy Radziwiłł wanted

the problem of faith to be discussed in Poland in a French way, with sword and fire.

Next, Niniński described in detail the faithlessness committed during St. Bartholomew's Day, when "violating pacta foedera according to the pope's will" people were murdered. Vilnius incidents of 1581, during which heretic books were burnt and Protestants' houses were attacked, are compared in Apologeticus to the Paris events, the leaders of which walked in "the innocent blood" up to their knees,

Where after big murder blood flooded

And butchers eventually became executioners

${ }^{74}$ S. Kot, Adieu à la Pologne (Kraków, 1930), pp. 13, 16, 20, 27 (reprint from Silva rerum 5 [1930]).

${ }^{75}$ On this cf. J. Tazbir, Arianie i katolicy (Warszawa, 1971), pp. 249-250.

${ }^{76}$ Cf. H. Barycz, "Kto był autorem poematu Apologeticus z 1582 r.?", Reformacja $w$ Polsce 6 (1934), p. 140. 
since official executioners did not want to murder Huguenots, "seeing that so many people were illegally killed".

In other places the Catholics terribly tortured the innocent people

The poem, which was to shock the readers, described in detail the kinds of these tortures, such as baking at a simmer or using winch to draw out guts. Description of the Paris events was ended with the following conclusion:

An awful act in which many thousands

were killed, including the admiral, without a single thought.

So this is how the guest is allowed to break the law?

The French have to stay disabled for a long time for this awful deed.

Disgrace will stay in their country for a long time,

God will deprive it of the sceptre and will give it to the right one. ${ }^{77}$

The problem also appeared in religious polemics: the aforementioned eye witness of the slaughter, Jan Łasicki, in his polemics with Possewin described how as a result of intolerant policy of French kings France was the area of civil wars, during which several thousand people were killed. And Charles IX invited many Huguenots and next ordered to murder them or to drown them in the Seine. It did not, however, bring the effect awaited by the cruel persecutors: of the martyrs' ashes new religious followers were born. And Herod, who ordered all this, left this world quite soon. Charles IX did it because of the persuasion of the pope, who advised him to make the massacre of Huguenots. ${ }^{78}$ Łasicki's apology was attached to the work by Wolan, who criticized Father Skarga; Wolan also saw the reasons of bloody wars taking place in France, Germany and the Netherlands in the intolerant policy of Catholics who persecuted the followers of true faith. And as the issue of a French candidate for the Polish throne was already invalid, the pope was considered the main inspirer of the Paris slaughter: he encouraged French cardinals to persuade the king to murder so many thousands people and admiral Coligny who was killed "in maxima pacis mutuaque concordiae stimulatione". Wolan wrote that such cruelty caused terrible indignation and Skarga is wrong to call its perpetrators

77 Apologeticus, to jest obrona konfederacyjej (1582), ed. E. Bursche (Kraków, 1932; Biblioteka Pisarzów Polskich, no. 84), pp. 9, 12, 64, 79-80.

78 J. Łasicki, Pro Volano... adversus Antonium Possevinum S.I. scriptum apologeticum (Vilnae, 1584), pp. 39, 48-49, 52, 83-84, 105. 
Catholics. It was Satan who was to blame, as he wanted human blood and slaughter. ${ }^{79}$

St. Bartholomew's Day is subject to clear allusions in the works (1596) of Ulrych Schober, Torun polemist of the end of the sixteenth century, who writes that the Warsaw Confederation saved Poland from the tragedy that France and the Netherlands experienced. ${ }^{80}$ Similar arguments were used in the anonymous brochure Oliva pacifera addressed to the well-known Calvinist magnate Adam Gorajski. It contains numerous references to the bloody religious wars going on in France. Henry Valois was, according to the author, the perpetrator of the Paris massacre; later, Poles successfully supported French Huguenots. If not for the Warsaw Confederation, Paris events would have happened in Poland. If it is breached, such a tragedy may happen, which is reflected in the religious riots in Cracow and Vilnius. The anonymous author precisely described the death of Coligny and tormenting his body. He also described in detail cruelties accompanying the slaughter (ripping the bellies of the dead in search of gold, ripping out foetuses from mothers' bodies etc.). St. Bartholomew's Day shows where a failure to comply with oaths taken leads to. God took revenge on the House of Valois - He exterminated their whole dynasty. Oliva pacifera being a strong warning against the effects of breaching the provisions of the Warsaw Confederation, kept referring to the French examples, especially the events of 24 August. ${ }^{81}$

Catholic polemists attempted to oppose these accusations. Hieronim Powodowski published in 1585 List Karola IX, króla francuskiego o zdradliwym sprzysiężeniu admirata $i$ pomocników jego na familija królewska i o skaraniu jego. ${ }^{82}$ This document contains the arguments which we already know; the king writes that he did not plan to attack Huguenots. Quite contrary, he visited the wounded Coligny, ordered to look for the attacker and announced "we were strongly against such cases". But the admiral thought about revenge, which he revealed to the Duke of Condé and Henry of Navarre and his other companions.

79 A. Wolan, Contra Scargae Iesuitae Vilnensis (Vilna, 1584), pp. 201, 208-209.

80 S. Tync, Ślazak Ulryk Schober, konrektor i dziatacz kulturalny toruński (15591598) (Kraków, 1960), pp. 208-209.

${ }^{81}$ Oliva pacifera missa ad Magnificum et Generosum virum Dn. Adamum Gorajski a Gorai a quodam A.M.I.C.O.I.C.M., 1597, passim, cf. esp. fol. $\mathrm{D}_{4}$ ver.

${ }^{82} \mathrm{H}$. Powodowski, Porozumienie kalwinistów francuskich z protestanty niemieckimi o pogodzeniu religijej swej $i$ o podniesieniu wojny przeciw katolikom... Przydany jest list króla francuskiego o zdradzie i pokaraniu admirata (Poznań, 1585), fol. $\mathrm{F}_{3} \mathrm{f}$. 
He encouraged them to perform an armed attack of Louvre on 27 August and kill (or imprison) the members of the royal family, including Charles IX. The king learned about "the treacherous plot against our House and blood" from the wife of Henry of Navarre, who told her everything because he had pangs of conscience. Duke of Condé and King of Navarre were called by the king and "they confessed all this and begged for mercy, which they were granted. So let Your Grace and the rest of the world see that it was nothing more than justice executed on the admiral, and we saved our lives and the kingdom, and punished treachery". These words end List Karola IX addressed to an unknown recipient.

To substantiate the accusation on Huguenots' plot, the anonymous delators who warned the king were replaced by the people known for their support of the admiral. This was the reason, more important than intent to present Duke of Condé and King of Navarre in good light, of placing their names in this letter. In another Catholic work (Okrucienstwa kacyrskie przeciw katolikom $w$ Anglijej) we read that only those who lost their life for true faith are martyrs. Therefore, a heretic may not be considered as such, especially if he acts against the legal rulers. Heretics "are themselves guilty of their death" because of their resistance. The circumstances of the admiral's death were described, which had been earlier "the subject of heretics' complaints spread throughout the world". They did not mention that Coligny "was the reason of it", since he wanted to take revenge on the king and all Catholics for the harm he suffered "from some unidentified person". "So if he wanted to be a martyr, he was not God's martyr but a victim of his anger and stubbornness". ${ }^{83}$ Huguenots' rebellion against the king was also mentioned by Jakub Ostrowski ${ }^{84}$ at the beginning of the seventeenth century. But generally, nobody in Poland dared - even in Catholic circles - to justify the Paris slaughter; attempts were only made to present it as a crackdown on political opponents.

The dispute affected historiography; Luther's follower Świętosław Orzelski in his work Bezkrólewia ksiag ośmioro discussed Monluc's attempts to smooth over the shock of the Paris massacre in Poland, he quoted big fragments of his speeches and assertions that Henry Valois, who had nothing to do with persecuting dissenters, in Poland

${ }^{83}$ Okrucieństwa kacyrskie przeciw katolikom w Anglijej... na polski przetożone (Poznań, 1582), fol. B ${ }_{\mathrm{IV}}$ rec.-ver.

${ }^{84} \mathrm{~J}$. Ostrowski, Dialog albo rozmowa katolika z ewangielikiem o znakach prawowiernego kościota (Kraków, 1604), p. 6. 
would also rule in a tolerant way. ${ }^{85}$ Arian Andrzej Lubieniecki was less restrained in his Poloneutichii and very negatively described Monluc's activity which he considered deceptive and mentioned that Monluc escaped to Basel just before the slaughter (because although he was a bishop, he backed heretics). Lubieniecki describes in detail the tragic end of the rulers who persecuted the true faith; first, he presented the death of Henry II (caused by a chip of spear), and next the events connected with the ruling of Charles IX. In fact his mother ruled, who pursuant to the advice of the House of Guise (especially the Cardinal of Lorraine) kept persecuting Huguenots: "until this awful Paris slaughter in which, according to rumours everywhere, up to 100000 people were murdered". God punished Charles IX: he fell seriously ill and people even say that "accepting his mother's advice and persecuting God's faithful followers, he was killed at the early age by his mother". Henry III was killed by a representative of the Catholics, "on whose wish he sinned and spilled innocent blood". In this way, by God's will, the whole House of Valois was exterminated. ${ }^{86}$

Obviously, Catholic historiography presented these events in a completely different light; Reinhold Heidenstein and Marcin Bielski (both of them, nota bene, ex-Protestants) tried to clear Henry Valois from all accusations. Heidenstein wrote that initially heretics considered him the perpetrator of the Paris massacre, during which Coligny and many other Huguenots were killed. Letters sent by the candidate to the Polish throne (to Monluc), and letters of the Bishop of Valencia showed, nevertheless, the innocence of Henry, who, eventually, became Polish king. ${ }^{87}$ And Bielski, who reprinted in extenso Monluc's speech (of 10 April 1573) defending the Duke of Anjou, without any comment, clearly placed himself on the side of the version spread by the Paris court. ${ }^{88}$ The same version was presented by Krzysztof Warszewicki in Rerum polonicarum... descriptio, where we read on Huguenots' preparations to a new civil war, in which they wanted to take revenge for the death of the admiral. At the same time Warszewicki described in detail the murder of Coligny, when he in vain begged the murderers led by Guise family for mercy; instead, they tormented the old man's

${ }^{85}$ Orzelski, op. cit., pp. 21, 52f., 86, 91, 144, 430.

${ }^{86}$ A. Lubieniecki, Poloneutichia, Wrocław, Ossoliński Library (Biblioteka Ossolińskich), MS 112, fols. 69-70, 141-143.

${ }^{87}$ R. Heidenstein, Rerum Polonicarum ab excessu Sigismundi Augusti libri XII (Frankfurt am Main, 1672), p. 29.

${ }^{88}$ M. Bielski, Kronika polska (Kraków, 1597), pp. 687-689. 
body. In Warszewicki's description of the Paris slaughter, during which the mob murdered Huguenots with no regard for age or sex, we can see a clear disapproval, especially that - as he stated - the murderers were not motivated by religious zeal but by hunting for loot and settling their personal score. From Paris the massacre spread to the provinces. ${ }^{89}$ Warszewicki's negative attitude relating to these events is also reflected in a note in his chronological specification of important historical events, where we read: "Matutina Bartholomianae in Gallis, in quibus Ugoniorum caedes per Gallias impune patratur. Anno 1572". 90

In the seventeenth century Paweł Piasecki repeated in his chronicle Monluc's basic arguments about Huguenots as the main factor of disturbance and that in revenge for hurting the admiral they wanted to attack the royal castle. The king persuaded by his advisors to prevent in advance the danger threatening him ordered to kill the leaders of the conspiracy; the mob, not caring about age or sex, murdered nearly four thousand Huguenots, and up to ten thousand victims were in the provinces. Because of St. Bartholomew's Day the civil war burst out in the whole of France with a new power. ${ }^{91}$ Piasecki's version was used by Kwiatkiewicz in Roczne dzieje kościelne, where we have a similar description of the course of events, with one difference, namely, that the author accuses the admiral that he wanted to engage France in the war going on in the Netherlands and advised attack on Spain. Since he was preparing the plot, "when king Charles learned about it, he ordered to prevent it and the Admiral's house was attacked and he was killed; the corpse was thrown out of the window, the head was cut off and he was hanged by his feet. When such opportunity occurred against Huguenots, Paris people attacked them and kept killing them for three days; the same happened in Aurelia, Lugdun, Tolossa, and Rotomagia until the king had to forbid these murders". ${ }^{92}$

89 Warszewicki, op. cit., pp. 15-17.

${ }^{90}$ Idem, Memorabilium rerum et hominum coaevorum descriptio (Cracoviae, 1585), fol. $\mathrm{Kk}_{4}$ ver. We find numerous statements on St. Bartholomew's Day in polemic materials reprinted in: M. Korolko, Klejnot swobodnego sumienia. Polemika wokót konfederacji warszawskiej $w$ latach 1573-1658 (Warszawa, 1974) - cf. esp., i.a., Respons w porywczq and Na przestroge... katolik odpowiada, 1592 (pp. 221, 225, 235, 248), or Przestroga i obrona, 1597 (ibidem, p. 308). Korolko also published the Polish translation of the brochure Oliva pacifera discussed by us.

${ }^{1}$ P. Piasecki, Chronica gestorum in Europa singularium recentiorum (Cracoviae, 1648), pp. 29-30.

92 J. Kwiatkiewicz, Roczne dzieje kościelne od roku pańskiego 1198 aż do lat naszych (Kalisz, 1695), p. 725. 
Quite a different version of events can be found in the Protestant circles; thus, we know that Joachim Pastorius dealt in his lectures conducted in 1665-1667 in the Gdańsk Gymnasium with the issues of religious tolerance and religious battles in France during the rule of Henry III and Henry IV Bourbon. ${ }^{93}$ The tragic Paris events were in vivid memory in the Royal Prussia region. In September 1622 a Gdańsk inhabitant Jan Mochinger delivered in Wittenberg a Oratio de nuptiis gallicis famosis laniena parisiensi, dedicated to Gdańsk pastors (also printed that year). Tolerant attitude of Stephen Báthory and Emperor Maximilian was juxtaposed by him with the Paris massacre which spread to the provinces and resulted in over 100 thousand victims. Mochinger provided a very detailed description of St. Bartholomew's Day events which were - according to the author - a climax of the long-lasting bloody persecutions of Protestants in France, the Netherlands and Germany. It shocked not only Emperor Maximilian but also the Turkish sultan; only the pope publicly demonstrated his joy. In Mochinger's opinion, the perpetrators of this slaughter, compared by him to the notorious Sicilian Vespers, did not avoid (including Henry III) God's punishment they deserved. ${ }^{94}$

In 1672 a theatre play De laniena parisiensi was staged in Toruń; it was devoted to St. Bartholomew's Day (alas, we do not know it). The problem of its genesis and effects was often mentioned in the French political journalism of the seventeenth century, preaching or historiography, as well as in the German, Czech or Hungarian literature. ${ }^{95}$ But as the authors of the recently published article on this subject rightly state, evaluation of the Paris events in the period of deep political (especially at the time of the Fronde) and religious (particularly at the end of the seventeenth century) crises must have been subject to drastically different interpretations and conciliation of attitudes was practically impossible. ${ }^{96}$

${ }^{93}$ L. Mokrzecki, Studium z dziejów nauczania historii. Rozwój dydaktyki przedmiotu w Gdańskim Gimnazjum Akademickim do schytku XVII w. (Gdańsk, 1973), p. 148.

${ }^{94}$ Gdańsk, PAS Library (Biblioteka PAN), sign. MA 3925/adl. 19: Johannis Mochingeri Dantiscani Oratio de nuptiis gallicis famosis laniena parisiensi... habita in frequentia academica Witebergae IIX Calend. Septembr. Anni MDCXXII.

95 A. Molnar, "Réactions à la Saint-Barthélemy en Bohème"; L. Makkai, "Pierre de la Ramée et l'Europe centrale," in: Actes du colloque "L'Amiral de Coligny".

96 Pintard, Carbie, op. cit., p. 828. They state that Bossuet condemned the massacre, but his opinion was announced as late as 1747 . 
Similarly, in the Polish written works of the seventeenth century we find quite opposite opinions on St. Bartholomew's Day; on the one hand, the Paris massacre was approved in words which in the Poland of "golden age" no one would dare to utter, ${ }^{97}$ and on the other, the praises of tolerance, quite frequent in the period of Enlightenment, often contain condemnation of the massacre. It suffices to recall the opinion of Dymitr Michał Krajewski, who in 1784 wrote proudly: "it is nice to read the history of our nation. It is the history of the most peaceful nation in the world. There is no St. Bartholomew's massacre, Sicilian Vespers, or subduing America". ${ }^{98}$

Trans. by Aneta Dylewska and Elżbieta Petrajtis

First published as: "Polskie echa Nocy św. Bartłomieja," Odrodzenie i Reformacja $w$ Polsce 20 (1975), pp. 21-44

The publication of this English translation has received additional funding from the Ministry of Science and Higher Education of the Republic of Poland

${ }^{97}$ E.g., Father Sz. Majchrowicz wrote (1764) that Charles IX who could not subordinate Huguenots was right in "directing his sword against them [- - and ordering to murder them on St. Bartholomew's Day"; the author states with satisfaction that several dozen thousands of victims were identified in Paris; idem, Trwatość szcześliwa królestw albo ich smutny upadek, Pt. 4 (Lwów, 1764), p. 325.

${ }^{98}$ D.M. Krajewski, Podolanka wychowana $w$ stanie natury, życie i przypadki swoje opisujaca, Pt. 2 (Warszawa, 1784), p. 25. 